ture. From the fact that $e^{2}$ enters into the investigation at all it is evident that this is only an approximation to the true distribution. In acc irdance with this Mr. Stoney has shown conclusively that in a compressed Crookes's layer the number of molecules moving parallel to the directisn of the transference of heat is greater than the number of th. se moving in any direction normal to it, so that the expressi nn Clausius derived from his assumption cannot be consdered as expressing the whoie state of affairs.

It is remarkable that to this order the expression for the pres. sure on any plane is the sa ue, hut Clausiu, gives another term in his expression for tie pressure on a pla e tormal to the irires. tion of transfer nce of heat to which he atraches. indeed, only an in efinite coefficient b-cause it is of the order $e^{2}$, and he was purpos.ly neglecting quentit $\mathrm{e}$; of that or ter. $\mathrm{H}=$ mignt have pruphesied, however, fro $n$ the excst uce of such a term that at disiances compa able with $e$ a force would be manifested such as Mr. Crookes has since discovered. Now this $e$ is by defin tion a quantity of the order of the len $<$ th of the mean path bet ween successive encourters, and hence these terms, varying with $e^{2}$ would besum $=$ of imp rtance at distances comparable witn the lenyth of this mean path.

I b-lieve, then, that I have shown that neither Clausius nor Clerk Maxwell have considered the case in dispute between $\mathrm{Mr}$ Stoney and Mr. Osborne Rryn llds, and thit as far as their investigations bear upon it they tend very much to strengthen Mr. Sinney's caie. I have also shown that Clausius was on the point of anticipating botn Croukes's forc- and Mr. Stoney's explanaion of it.

Trinity College, Dublin

\section{Prof. Eimer on the Nervous System of Medusa}

SOME of your readers may renember that a few months ago I published in NATUke an abstract of a lecture which I had delivered at the Royal Institution on "The Evolution of Nerves." In this lecture I mainly treated of my recent researches on the nervous system of Medusce; and stated, among other things, that I was the first to publish the observation concerning the paralysing effect of removing the margins of nect scalyces. ${ }^{1}$ Witbin the la:t few days, however, I have received a communication from Prof. Eimer, of Tübingen, informing me that he has the right to claim priority as regards the publishing of this observation. I therefore send you this note in order that I may rectify the injustice which I previously did to Dr. Eimer in your columns.

The facts of the case are simply these: Dr. Eimer made his observation a few months later than I made mine; but, as he communicated his observation within a few weeks after he had made it to the Physikalisch-medicinischen Gesellichaft zu Wiirzburg, his publication preceded mine. He has therefore the right to claim priority as regards this observation, and also as regards some further physiological experiments by which he followed it up-all of which I have been careful to detail in my Royal Society publications.

So much in justice to Dr. Eimer. In justice to myself I must now explain that, although, since the publication of my Croonian lecture in 1875 , I have been aware that Dr. Eimer's work was independent of mine, it is only within the last few days I have learned from him that the publication of his work was prior to mine. The reason of the ambiguity on this head is explained in a newly-pub ished memoir by Dr. Eimer, where it is stated that his previous memoir, having been published in the Wiirz. burg Verkandlungen without its proper title-page, the initials "d. $/ . "$ ("this year"), which occur in the paper itself, refer, not to the date on the volume, but to the year preceding. My prolonged ignorance concerning Dr. Eimer's claim to priority, has, therefore, not been due to any fault on my part; and as in all $\mathrm{my}$ previous publications on this subject $I$ have spoken of Dr. Eimer's work as subsequent to my own, I may here add that I think the fact of his having been so long in acquainting me with the true standing of the case, displays a laudable spirit of indifference on his part to the matter of mere priority.

18, Cornwall Terrace, Regent's Park, N.W. GEORGE J. ROMANES

\section{Mr. Crookes and Eva Fay}

After Mr. Cooper's courteous explanation which appeared in last week's NATURE (p. 183), I gladly exonerate him from blame.

I I first published this obs:rvation in a note to NATURE, which appeared in November, 1874 .
To the publication of my letter in the Banner of Lisht, if Mr. Cooper thought it likely to do Eva Fay any grod, I have no ground of complaint; but what I did, and do now, protest against, is the unauhurised publication of a lithographed facsimile of my letter in such a manner, an $f$ wi'h such surroundiugs, as to leave no dount that the intention was to throw dis.redit on my testimony as a trustworthy experimentalist.

I am glad to find that Mr. Coop $\mathrm{r}$ was no party to this breach of etiquette, a d I willingly with traw any expressions in my letter in NATURE (vol. xviil, p. 43) which may appear to reflect on him.

As a fitting climax to this controversy, may I request you to pub ish the subjwed le ter from Eva Fay, whicb appeared in the Bann-r of Light for December 22 list?

London, Janutry 7

Willtali CRUOKES

"To the Editor of the Banner of Light, Buston, U.S.,

December 22

"I wish to state a few facts in reference to an article in your paper of December 8, reterring to myself, in a letter of Mr. Crookes on Dr. Carpenter's atıack.

"First, it is untrue that Mr. Cronkes gave me a letter speaking of th: spiriruslistic nature of my mwi'estaions, and referrng to Feliows of the Ruval society. The only tetter, to m, knowledge, that Mr. Croukes ever wrote regarding my msiumship (with the exception of the one written t, Mr. Cooper) appeared in the London Daily Telegraph, and other journals, March II, 1875 .

"Second, in reply to Dr. Cirpenter's statement that an offer was made by un managers in May, 1875 . of an equivalent sum of money for me to 'expose the whole affair,' I will now say to Dr. Carpenter, as I did to my managers, I have nothing to expose.

"I am in receipt of a letter, dated November 18,1877 , asking me if I will fix a price to visit England under the title of an 'Exposée,' and show how I am supposed to have hoodwinked members of the Ruyal Society.

"My reply was as follows:- As poor as I am, and as clever as I am supposed to be by Dr. Carpenter and others, I am obliged to decline your tempting proposition to replenish my exchequer by attempting impossibilities. I sincerely hope to be able to maintain myself and child in a more honourable occu. pation.'

"Akron, Ohio, December ro, 1877 " "AnNie Eva Fay

\section{Volcanic Phenomena in Borneo}

Mr. Wallace, in his work on the "Geographical Distribution of Animals," has the remark that no volcano, active or extinct, is known to exist within the area of the island of Borneo, notwithstanding that it is almost environed by a volcanic belt in full activity at a short distance. In fact, it seems to be generally understood that this vast island now represents, and has colltinued to represent for long past time, a perfecrly quiescent area in so far as manifestations of subterranean energies are concerned. This view is doubtless strictly correct in regard to the existence of any volcanic vent which is now in action, or which has been so within the historical period; but it would be erroneous to deduce from it, as seems natural to do at first sight, the inference that the area is one of entire quiescence, or that it has been so free from volcanic action in any but the most recent times.

Speaking solely with reference to the north-west district, it may be observed that shocks of earthquake have been recorded more than once by credible witnesses during late years, viz., one in June, 1874 , a second in June, 1876, an 1 two more in July, 1876. These were recorded the first in $\mathrm{S} \star \mathrm{dong}$, the three others in Saràwak. According to native testimony, slicht shocks are by no means rare, and a severe one is particularly held in remembrance, which took place seventy or eighty years ago, and was accompanied by " a rain of ashes." Seismometrical observation would probably show that they are very frequent. These shocks seem to indicate that the island is directly affected by the proximity of the volcanic band above referred to.

As for the period of time prectoning the historical epoch, there are not wanting signs that this parc of Borneo was the theatre of a display of considerable volcanic energy, and it has yet to be shown that its date of activity was anteriur to the deposition of the sandstone conglomerate formation of the country, which is, with the exception of very recent deposits, the most modern of the stratified rocks of this part of the istand, it having been asigned-I know not with how much truth-to a later tertiary 